\title{
The Effect of Enterprise on Managerial Innovation Capacity
}

\author{
Israel Odion E. Idewele ${ }^{1}$, Ruth Angbazo Andah', Muhammad Ridwan ${ }^{3}$ \\ ${ }^{1}$ Faculty of Economics and Administrative Sciences, Cyprus International University, Turkey \\ ${ }^{2}$ Department of Business Administration, Nasarawa state university, Keffi, Nigeria \\ ${ }^{3}$ Universitas Islam Negeri Sumatera Utara, Indonesia \\ idewelei@veritas.edu.ng,ruthandah68@gmail.com,bukharyahmedal@gmail.com
}

\begin{abstract}
Business can offer an upper hand to a venture through hazardous choices that pay off improve creative items, administrations and markets in a troublesome managerial condition and by moving proactively to command a serious market. This investigation means to inspect the connection among business enterprise and managerial innovation capacity by considering subfactors, for example, creativity, proactiveness and chance taking, just as to investigate the connection between managerial innovation capacity and management performance. The examination decides the degree to which policy account and management support for little and medium-sized ventures (SMEs) assume the job of directing factors. Structure/technique/approach: Data assortment was done in 820 SMEs. To check the speculations, Covariance Structure Analysis was led utilizing EQS6b. Discoveries/results: The discoveries demonstrate that enterprise affects key arranging, innovative work, and innovation commercialisation. This examination found that managerial innovation limits effectsly affect management performance. Furthermore, this examination affirmed that when business enterprise influences managerial innovation exercises, policy financial support and management support fill in as arbitrators. Useful ramifications: Small and medium-sized undertakings should upgrade their innovation capacity and extend inventive business enterprise and policy account to carry out seriousness, endure and show constant turn of events and development in an evolving situation. Inventiveness/esteem: The investigation furnishes SME with data they can use to build their attention to interior managerial innovation exercises, which are the first wellsprings of upper hand, and help advance innovative work $(R D)$ and authoritative management for nonstop fortification of innovation capacity. The examination gives SME data they can use to expand their familiarity with inside managerial innovation exercises, which are the first wellsprings of upper hand, and help advance $R D$ and authoritative management for consistent support of innovation capacity.
\end{abstract}

Keywords

enterprise; managerial innovation capacity, policy financial support; management support; management performance

\section{Introduction}

Enterprise requires imaginative personalities that face challenges to unequivocally challenge and make new markets. Numerous investigations find that business enterprise builds firm development, productivity, upper hand and eventually endurance (Zahra, Covin, and Slevin, 1995; Zahra, 1996). Consequently, a business enterprise can offer an upper hand to an undertaking through hazardous choices that pay off in the advancement of inventive items administrations and markets in a troublesome managerial condition and by moving proactively to rule a serious market (Covin and Slevin, 1991). Previous studies 
have separated enterprising into three parts - innovativeness, proactiveness and risk-taking (Covin and Slevin, 1989; Covin and Wales, 2018; Dimitratos, Voudouris, Plakoyiannaki, and Nakos, 2012; Lassen, Gertsen, and Riis, 2006; Miller, 1983). The questions used in existing studies were rearranged to create 12 questions for this student (Covin and Wales, 2018; Hisrich and Brush, 1984; Miller, 1983; Zahra, 1996). In this study, managerial innovation exercises were divided into three subitems by identifying basic things used in existing studies (Burgelman et al., 2009; Guan et al., 2006; Wang et al., 2008; White and Bruton, 2007; Yam et al., 2004). A total of 1025 responses were received, and 820 were selected for measurable investigation after excluding invalid responses, for example, missing marks and cross marking. The response rate to this survey was over $80 \%$. Managerial innovation limit is the comprehensive capacity to create an incentive by developing, introducing and adopting the new knowledge and processes to manufacture and gracefully products and services. It comprises strategic arranging limit (six inquiries), $\mathrm{R} \& \mathrm{D}$ limit (six inquiries) and technology commercialisation limit (for inquiries).

The control variables utilized in this study include service year, corporate size and industry. Size was measured by the number of full-time representatives, and industry was classified according to the Korean standard industrial arrangement into manufacturing, construction, distribution, services, and discount and retail trade. This study aims to examine the relationship among entrepreneurship and managerial innovation limit by considering subfactors, for example, innovativeness, proactiveness and risk-taking, just as to explore the relationship between managerial innovation limit and the executives performance. Precisely 820 subjects responded to this study questionnaire, and the study test comprised CEOs of SMEs from Korea. The organizations that had been doing business for fewer than 5 years comprised $12.9 \%(\mathrm{n}=106)$ of the example, while $18 \%(\mathrm{n}=148)$ had been founded 16-20 years prior to the study, with $30.9 \%(\mathrm{n}=253)$ being in presence for more than 20 years. Manufacturing ranked first among business types at $39.9 \%$, followed by specialized service organizations, broadcast communications, retail organizations and construction organizations. Organizations with fewer than five representatives comprised $29.1 \%(\mathrm{n}=239)$, while firms with more than 50 workers comprised $6.2 \%(\mathrm{n}=51)$.

In this study, managerial innovation activities were divided into three subfactors strategic planning, R\&D and technology commercialisation - to determine their relationships with management performance. In addition, entrepreneurship is also divided into three subfactors - innovativeness, proactiveness and risk-taking - to analyse their relationships with managerial innovation activities and management performance. Although there are differences across enterprises according to their attributes, managerial innovation activities, policy finance and management support were found to be closely connected to management performance in this study. It would be useful to conduct indepth follow-up studies by further subdividing the factors comprising managerial innovation capacity. 


\section{Review of Literature}

\subsection{Business Enterprise}

As indicated by Drucker (1985), business visionaries find new viewpoints in existing items and administrations, cause upheavals, make new qualities and investigate the changes. Schumpeter (1934) viewed a business visionary as a trailblazer who executes an adjustment in a market through new blends. Such pioneering traits contain business enterprise. Mill operator (1983) recognized three significant parts of the business: ingenuity, proactiveness, and. Chance takes (Covin and Wales, 2018; Frishammar and Hart, 2007; Van Zyl and Mathur-Helm, 2007). Specialists progressively concur that business enterprise improves hierarchical performance (Rauch, Wiklund, Lumpkin, and Frese, 2009; Zahra, Jennings, and Kuratko, 1999). Innovative direction is a center idea in the writing on business (Bock and George, 2011). A few researchers note that the three fundamental components of business enterprise, to be specific, innovation, proactiveness and hazard taking, consolidate to shape the essential vital pioneering direction (Covin and Slevin, 1989; Covin and Wales, 2018). This build may have constrained utility on the grounds that enterprising direction may essentially be an inclination to take part in pioneering conduct (Dessand Lumpkin, 2005; Miller, 2011; Short, Broberg, Cogliser, and Brigham, 2009).

Innovation capacity is, at that point, the capacity of an undertaking to effectively actualize and apply new plans to items, administrations and procedures (Burgelman, Christensen, and Wheelwright, 2009; Burns and Stalker, 1961; Dess and Lumpkin, 2005; Guan and Ma, 2003). Since innovation exercises start with inside analyzing an association to decide its center capacity, contrasts in innovation exercises between ventures are identified with explicit endeavor assets. Innovation capacity strengthens seriousness (Guan et al., 2006). Particularly for adventure undertakings, the capacity to grow new advancements and apply them to items and administrations more rapidly than contenders is critical, and an elevated level of innovation capacity influences mechanical innovation performance. Other late investigations characterize innovation capacity from an extensive viewpoint that incorporates innovative work $(\mathrm{R} \& \mathrm{D})$ and the commercialisation of innovation (Guan et al., 2006; Wang, Lu, and Chen, 2008; Yam, Pun, and Tang, 2004). Albeit existing examinations consider just direct mechanical improvement as a factor that influences innovation comparable to innovation capacity, Wang et al. (2008) considered quantitative and enthusiastic components of the creative dynamic capacity to incorporate backhanded management exercises that support and encourage innovation of direct advancements. Such innovation capacity influences outside joint effort exercises. To use outside joint effort (Albert et al., 2000) as a methods for making up for missing assets, a venture must have the inside capacity to retain and utilize outer assets (Cohen and Levinthal, 1990; Lipparini and Sobrero, 1994; Tsai, 1991).

In an investigation that analyzed the connection between the capacity of assembling endeavors to utilize government support strategies and innovation performance, the capacity of an undertaking to use outside support was found to positively affect the commercialisation of advances (Lee and Limb, 2012). This outcome proposes a constructive outcome of the capacity to utilize government support strategies on innovation performance (Guan et al., 2006; Wang et al., 2008; Yam et al., 2004). J. Jose Prabhu (2020), completed an investigation on the Perspectives and Empirical Study of Engineering College Students towards Entrepreneurship, and discovers that angles towards business venture impressively influence the by and large parental parts of mentalities towards business. Ade Yusuf (2021),completed an investigation to decide the impact of item 
development and Brand Image on Consumer Purchase Decisions of OPPO Smartphone Products in South Tangerang City, receiving logical examination with investigation procedures utilizing measurable examination with relapse testing, connection, assurance, and speculation testing, He decovered that item advancement significantly affects buying choices by $42.1 \%$, theory testing acquired $t$ count $>t$ table or $(8.274>1.986)$.

Business not just carries essential vitality to an association and mitigates the impacts of bureaucratic formalism yet additionally fortifies corporate seriousness in the worldwide condition. Some contend, in any case, that this zone of grant experiences an absence of hypothetical concession to the different terms identified with business (McFadzean, O'Loughlin, and Shaw, 2005). It is broadly recognized that corporate business is connected with corporate execution (Nihat, 2006; Vozikis, Bruton, Prasad, and Merikas, 1999; Yang, Li-Hua, Zhang, and Wang, 2007; Zahra and Garvis, 2000). For example, Yang et al. (2007) revealed that every one of the center elements of business enterprise differentiatedly affects corporate execution. Nihat (2006) found that a company's work force the executives technique intervenes the connection among business and execution. Zahra and Garvis (2000), who talked about corporate business enterprise and execution in different nations, and Vozikis et al. (1999), who looked into the connection among business enterprise and value creation, introduced comparative perspectives. This study characterizes managerial innovation capacity as an element of vital arranging, $R \& D$ and commercialisation exercises dependent on past investigations.

\subsection{Research Hypotheses}

A few examinations have underscored that the criticalness of business lies in its capability to enable the association's top management to portray the reason for the association, support the association's vision and define an approach to accomplish points of interest over contenders (Al-Mamun, Kumar, Ibrahim, \& Bin Yusoff, 2017, p. 54). Business enterprise has reliably been seen as exceptionally noteworthy in firm performance and give credits to the association (Covin and Slevin, 1991; Miller, 1983).

Past examinations recommend that business enterprise decisively affects management performance, however undertakings can accomplish persistent development just by changing over business into innovation capacity to keep up and create business enterprise in a changing managerial condition. Business enterprise effectsly affects management performance as well as is connected to performance through innovationrelated exercises, for example, R\&D, ICT and systems administration (Lee and Limb, 2012). The creative management style of business people was found to influence exploratory innovation exercises and add to confirmation of new items (Lee and Limb, 2012). Moreover, business enterprise likely influences managerial innovation capacity since it is reflected in management methodology. As needs be, this examination tests the accompanying theories:

H1: Entrepreneurship will emphatically impact the vital arranging capacity, a subfactor of managerial innovation exercises.

H2: Entrepreneurship will emphatically impact the R\&D capacity, a subfactor of managerial innovation exercises.

H3: Entrepreneurship will emphatically impact the innovation commercialisation capacity, a subfactor of managerial innovation exercises.

As appeared by existing examinations on business and managerial innovation capacity, such factors influence different results of management performance. Managerial innovation capacity is firmly identified with management performance and has beneficial 
outcomes (Drnovsek and Glas, 2002; Hmieleski and Baron, 2008; Westerberg, Singh, and Hackner, 1997). Past examinations contend that to make due in the serious market, firms must support their performance through constant innovation since innovation assumes a significant job in firm performance. Managerial innovation upgrades firm performance on the grounds that inventive exercises make a firm increasingly serious and changes an association's inner capacities (Alzuod and Kharabsheh, 2015; Rogers, 1998). Past examination found that managerial innovation in undertakings is firmly identified with the firm performance measurements and the nature of administrations (benefit and piece of the overall industry as significant non-financial firm performance pointers), and decidedly expands consumer loyalty.

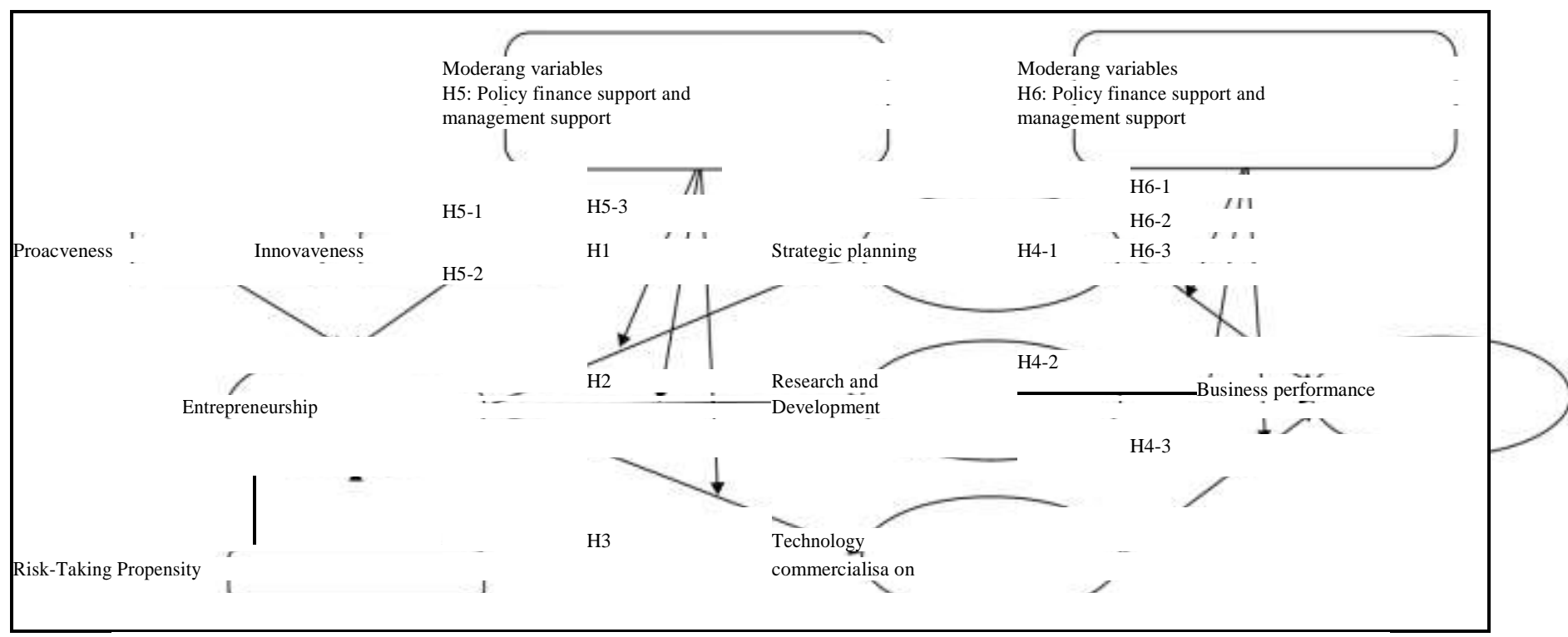

Figure 1. Conceptual framework

what's more, Return of Investment (ROI) (Daugherty, Chen, and Ferrin, 2011; Liao, Wang, Chuang, Shih, and Liu, 2010; Uzkurt, Kumar, Kimzan, and Eminoglu, 2013). The accompanying theory mirrors the forecast that managerial innovation exercises will influence management performance.

H4: Managerial innovation factors (vital arranging capacity: H4-1: R\&D capacity: H4-2; and innovation commercialisation capacity: H4-3) will effectsly affect management performance.

Performance can be summed up as an idea, which incorporates responsiveness, viability, efficiency, quality and idealness. A performance standard is a scale that demonstrates how much a management objective has been practiced. A performance standard table likewise shows how much a management objective has been practiced. Since characterizing and estimating performance is a crucial advance in performance improvement, performance estimation is critical (Lee and Limb, 2012; Wang et al., 2008). This study sees policy fund and management support as possibly unequivocal variables in the achievement or disappointment of SMEs. In like manner, the accompanying theories mirror the forecast that policy money and management support for SMEs, which are seen probability factors, are identified with managerial innovation exercises and management performance. 
H5: Policy money and management support will have a directing impact when business influences managerial innovation.

H6: Policy money and management support will have a directing impact when managerial innovation influences management performance.

The accompanying model was made to achieve the motivation behind this investigation dependent on the hypotheses and conversations introduced (see Figure 1).

\section{Research Methods}

\subsection{Procedures}

Information were gathered from SMEs in Korea. These organizations were picked in view of their significance in advancing financial improvement in the nation and were chosen from the individuals from the K-BIZ (Korean Federation of Small and MediumSized Enterprises). A poll was dispersed to SMEs working organizations with the assistance of policy financing offices, including the Korea Credit Guarantee Fund, the Small and Medium Business Corporation and the Korea Development Bank. The creator of this examination gave adequate clarification and asked the (CEOs) of the undertakings to round out the poll as a self-managed study. Individuals from K-Biz took an interest in this examination. The analysts reached the administrators of the organizations by email and telephone and afterward clarified the venture and gave the overview. Before the study, a starter study was completed in 50 SMEs. Information assortment was done by online review, face to face visits and postal mail. Willing member organizations were then coordinated to the online review site. What's more, the specialists visited the organizations on a concurred date and requested that the members round out the polls as self-managed reviews. Respondents were given gift vouchers as pay by the analysts. An aggregate of 1025 reactions were gotten, and 820 were chosen for factual examination subsequent to barring invalid reactions, for example, missing imprints and cross stamping. The reaction rate to this review was over $80 \%$. The review survey comprised of two sections, with segment addresses set toward the start. The second piece of the overview remembered inquiries for business, managerial innovation capacity, management performance, and policy account and management support, in the wake of barring invalid reactions. Likewise, dependability and factor investigations were led.

\subsection{Descriptive Analysis}

Exactly 820 subjects responded to this study questionnaire, and the study sample comprised CEOs of SMEs from Korea. As shown in Table 1, companies that had been in business for fewer than 5 years comprised $12.9 \%(\mathrm{n}=106)$ of the sample, while $18 \%(\mathrm{n}=$ 148) had been founded 16-20 years prior to the study, with $30.9 \%(\mathrm{n}=253)$ being in existence for more than 20 years. Manufacturing ranked first among business types at $39.9 \%$, followed by specialised service businesses, telecommunications, retail businesses and construction companies. Companies with fewer than five employees comprised $29.1 \%$ $(\mathrm{n}=239)$, while firms with more than 50 employees comprised $6.2 \%(\mathrm{n}=51)$. 
Table 1. Sample characteristics $(n=820)$

\begin{tabular}{llll}
\hline Variable & Characteristic & Frequency & $\%$ \\
\hline Sex & Male & 734 & 89.5 \\
Industry & Female & 86 & 10.5 \\
& Manufacture: Electronics & 90 & 11 \\
& Manufacture: Machinery & 72 & 8.8 \\
& Manufacture: Petroleum & 54 & 6.6 \\
& Manufacture: Clothes & 111 & 13.5 \\
& Construction & 74 & 9 \\
& Distribution & 33 & 4 \\
& Telecommunications & 83 & 10.1 \\
& Services & 154 & 18.8 \\
& Wholesale & 109 & 13.3 \\
Working years & Others & 40 & 4.9 \\
& Under 5 & 106 & 12.9 \\
& 6-15 & 321 & 39.1 \\
Size & 16-20 & 140 & 17.1 \\
& Over 20 & 253 & 30.9 \\
& Under 5 employees & 239 & 29.1 \\
& 6-30 employees & 441 & 63.7 \\
& 31-50 employees & 89 & 10.9 \\
& More than 50 employees & 51 & 6.2 \\
\hline
\end{tabular}

Table 2. Results of factor analysis

$\begin{array}{lllll}\text { Construct } & \text { Items } & \text { FL } & \text { Eigenvalues } & \text { \% of variance } \\ \text { Independent variables }{ }^{\dagger} & & & & \\ \text { Innovativeness } & \text { INN1 } & 0.855 & - & - \\ & \text { INN2 } & 0.810 & - & - \\ & \text { INN3 } & 0.797 & - & - \\ \text { Proactiveness } & \text { INN4 } & 0.785 & - & - \\ & \text { PRO1 } & 0.832 & - & - \\ & \text { PRO2 } & 0.796 & - & - \\ \text { Risk-taking propensity } & \text { PRO3 } & 0.777 & - & - \\ & \text { RTO4 } & 0.768 & - & - \\ \text { Factor 1 } & \text { RTP2 } & 0.813 & - & - \\ \text { Factor 2 } & \text { RTP3 } & 0.778 & - & - \\ \text { Factor 3 } & - & - & 6.362 & - \\ \text { Moderating variablest } & - & - & 1.559 & 12.99 \\ \text { Policy financial support } & - & - & 1.265 & 10.54 \\ & \text { PF1 } & 0.865 & - & \\ & \text { PF2 } & 0.840 & - & - \\ & \text { PF3 } & 0.752 & - & - \\ \text { ME4 } & 0.655 & - & - \\ \text { Management support } & \text { PF5 } & 0.645 & - & - \\ \text { Factor 1 } & \text { MS1 } & 0.838 & - & - \\ \text { Factor 2 } & \text { MS2 } & 0.763 & - & - \\ \text { Dependent variables§ } & \text { MS3 } & 0.725 & - & - \\ & - & - & 4.914 & 61.43 \\ & - & - & 1.118 & 13.97 \\ & & & & \end{array}$




\begin{tabular}{|c|c|c|c|c|}
\hline \multirow[t]{6}{*}{ Strategic planning } & SP1 & 0.802 & - & - \\
\hline & SP2 & 0.792 & - & - \\
\hline & SP3 & 0.788 & - & - \\
\hline & SP4 & 0.744 & - & - \\
\hline & SP5 & 0.705 & - & - \\
\hline & SP6 & 0.665 & - & - \\
\hline \multirow[t]{6}{*}{ Research and development } & RD1 & 0.884 & - & - \\
\hline & RD2 & 0.859 & - & - \\
\hline & RD3 & 0.836 & - & - \\
\hline & RD4 & 0.814 & - & - \\
\hline & RD5 & 0.800 & - & - \\
\hline & RD6 & 0.653 & - & - \\
\hline \multirow{3}{*}{$\begin{array}{l}\text { Technology } \\
\text { commercialisation }\end{array}$} & $\mathrm{TC} 1$ & 0.773 & - & - \\
\hline & $\mathrm{TC} 1$ & 0.736 & - & - \\
\hline & TC1 & 0.731 & - & - \\
\hline \multirow[t]{4}{*}{ Management performance } & MP1 & 0.821 & - & - \\
\hline & MP2 & 0.816 & - & - \\
\hline & MP3 & 0.813 & - & - \\
\hline & MP4 & 0.711 & - & - \\
\hline Factor 1 & - & - & 7.267 & 36.3 \\
\hline Factor 2 & - & - & 3.622 & 18.1 \\
\hline Factor 3 & - & - & 1.727 & 8.64 \\
\hline Factor 4 & - & - & 1.508 & 7.54 \\
\hline
\end{tabular}

INN, innovativeness; PRO, proactiveness; RTP, risk-taking propensity; SP, strategic planning; TC, technology commercialisation; PF, policy finance; MS, management support; MP, management performance; RD, research and development; FL, factor loadings.

$\dagger, 76.55 \%$ of total variance extracted; $\$, 75.40 \%$ of total variance extracted; $\S, 70.62 \%$ of total variance extracted.

\subsection{Appraisal of the Estimation Model}

This study evaluated normal technique inclination utilizing exploratory factor examination (EFA) with greatest probability. The measure of false covariance shared among factors due to the basic strategy utilized in gathering information is called regular technique fluctuation (Buckley, Cote, and Comstock, 1990). The factor investigation was executed by the most extreme probability extraction technique with varimax pivot. Varimax pivot was utilized to distinguish factors that may show expected builds, and normalized factor loadings were analyzed at 0.5 or more on every likely develop. The aftereffect of a Bartlett's trial of sphericity was seen as critical $\left(\chi^{2}=5361.5, \mathrm{df}=76, \mathrm{p}<\right.$ 0.001 ), while the Kaiser-Meyer-Olkin proportion of examining ampleness was 0.877 for all the factors. The information were hence reasonable for investigation (see Table 2).

In this way, the investigation checked for conceivable regular technique change with Harman's single-factor test (Podsakoff and Organ, 1986) for (in)dependent factors. As indicated by this methodology, normal strategy difference is available if a solitary factor represents most of the covariance in the needy and free factors. The examination found no prevailing component rising up out of the factor investigation, suggesting that basic technique change is certifiably not a major issue. An EFA of the entirety of our scale things uncovered components for free factors clarifying $76.55 \%$ and the last factor for subordinate factors clarifying $70.62 \%$ of the complete difference. This investigation 
recommended that the information test utilized in the examination is likely not tainted by regular technique inclination (Podsakoff, MacKenzie, Lee, and Podsakoff, 2003).

The inner consistency of the measures was assessed by Cronbach's alpha, which was additionally used to test the dependability of the examination's instruments and, as appeared in Table 3, the scale reliabilities (Nunnally and Bernstein, 1994). In each of the nine develops, Cronbach's alpha surpasses the standard acknowledgment standard of 0.70 . As appeared in Table 3, the investigation's normal change removed (AVE) likewise fulfills the standard of 0.5 , which implies that the estimation lists fulfill the necessity for focalized legitimacy. The methods for the squares of the relationship coefficients $\left(\mathrm{r}^{2}\right)$ are littler than the AVE, bringing about an AVE more noteworthy than the methods for the squares of the connection coefficients $\left(\mathrm{r}^{2}\right)$, additionally guaranteeing that the information gathered for confirmation have adequate discriminant legitimacy (Bagozzi and Yi, 1988; Fornell and Larker, 1981; Wixom and Watson, 2001).

\section{Results and Discussion}

\subsection{Hypotheses Tests}

The causal model's goodness of fit for each measurement model satisfies the criteria (Bentler, 2004).

Table 3. Average variance extracted, Cronbach's alpha and correlation matrix

\begin{tabular}{llllllllllll}
\hline \multicolumn{2}{l}{ Variables A } & AVE & 1 & 2 & 3 & 4 & 5 & 6 & 7 & 8 & 9 \\
\hline INN & 0.929 & 0.753 & 1 & - & - & - & - & - & - & - & - \\
PRO & 0.938 & 0.733 & 0.433 & 1 & - & - & - & - & - & - & - \\
RTP & 0.720 & 0.623 & 0.110 & 0.124 & 1 & - & - & - & - & - & - \\
SP & 0.870 & 0.721 & 0.229 & 0.188 & 0.081 & 1 & - & - & - & - & - \\
RD & 0.913 & 0.742 & 0.003 & 0.001 & 0.017 & 0.199 & 1 & - & - & - & - \\
TC & 0.810 & 0.694 & 0.281 & 0.119 & 0.037 & 0.301 & 0.092 & 1 & - & - & - \\
PF & 0.883 & 0.734 & 0.241 & 0.379 & 0.087 & 0.088 & 0.000 & 0.069 & 1 & - & - \\
MS & 0.872 & 0.723 & 0.171 & 0.147 & 0.048 & 0.052 & 0.013 & 0.047 & 0.413 & 1 & - \\
MP & 0.890 & 0.752 & 0.203 & 0.338 & 0.134 & 0.141 & 0.003 & 0.137 & 0.287 & 0.116 & 1 \\
\hline
\end{tabular}

INN, innovativeness; PRO, proactiveness; RTP, risk-taking propensity; SP, strategic planning; TC, technology commercialisation; PF, policy finance; MS, management support; MP, management performance; $\mathrm{RD}$, research and development.

$*, \mathrm{p}<0.05$.

Table 4. Moderating effects of policy financial and management support

\begin{tabular}{lllllll}
\hline $\begin{array}{l}\text { Dependent } \\
\text { Variable }\end{array}$ & $\begin{array}{l}\text { Interaction } \\
\text { Effect }\end{array}$ & $A$ & $T$ & $p$ & $\begin{array}{l}\text { Adjusted } \\
R^{2}\end{array}$ \\
\hline SP & - & - & - & - & 0.215 & $113.2^{* * *}$ \\
& ENTRE * PF & 0.661 & 12.28 & 0.000 & - & - \\
R\&D & ENTRE * MS & 0.271 & 5.04 & 0.000 & - & - \\
& - & - & - & - & 0.050 & $3.22^{* *}$ \\
& ENTRE * PF & 0.003 & 0.053 & 0.958 & - & - \\
TC & ENTRE * MS & 0.091 & 1.50 & 0.133 & - & - \\
& - & - & - & - & 0.160 & $78.8^{* * *}$ \\
MP & ENTRE * PF & 0.573 & 10.29 & 0.000 & - & - \\
& ENTRE * MS & 0.239 & 4.29 & 0.000 & - & - \\
& - & - & - & - & 0.344 & $72.5^{* * *}$ \\
& SP * PF & 0.415 & 8.173 & 0.000 & - & - \\
& $\mathrm{RD} * \mathrm{PF}$ & 0.095 & 2.387 & 0.017 & - & - \\
& $\mathrm{TC} * \mathrm{PF}$ & 0.260 & 5.810 & 0.000 & - & -
\end{tabular}




$\begin{array}{llllll}\mathrm{SP} * \mathrm{MS} & 0.352 & 6.165 & 0.000 & - & - \\ \mathrm{RD} * \mathrm{MS} & 0.166 & 3.693 & 0.000 & - & - \\ \mathrm{TC} * \mathrm{MS} & 0.253 & 4.885 & 0.000 & - & -\end{array}$

ENTRE, entrepreneurship; SP, strategic planning capacity; R\&D, research and development; TC, technology commercialisation; PF, policy finance; MS, management support; MP, management performance; RD, research and development.

$* * *, \mathrm{p}<0.001 ; * *, \mathrm{p}<0.05$.

Subsequently, the outcomes show that the examination presumptions stay inside worthy limits. To test auxiliary connections, the theorized causal ways were evaluated. The outcomes are appeared in Table 4 and Figure 2. The causal model's integrity of fit is demonstrated by $\square^{2}=1023.5$, df $=532, p=0.000$, CFI $=0.950$, GFI $=0.932$, AGFI $=$ $0.913, \mathrm{NFI}=0.927, \mathrm{NNFI}=0.932, \mathrm{SRMR}=0.091$ and RMSEA $=0.053$. Subsequently, the presumptions stay inside adequate limits. Theory1 expect that business enterprise affects key arranging. The outcomes demonstrate that enterprise positively affects vital arranging (way coefficients: $\gamma=0.504(0.582), z=16.71, \mathrm{p}<0.001$ ). Speculation 2 expect that business affects $R \& D$. The outcomes demonstrate that business enterprise positively affects R\&D (way coefficients: $\gamma=0.075(0.108), \mathrm{z}=2.152, \mathrm{p}<0.05$ ).

Speculation 3 accept that enterprise affects innovation commercialisation. The outcomes show that enterprise positively affects innovation commercialisation (way coefficients: $\gamma=0.453$ (0.642), $\mathrm{z}=14.52, \mathrm{p}<0.001$ ). Consequently, $\mathrm{H} 1, \mathrm{H} 2$ and $\mathrm{H} 3$ are supported.

Speculations 4-1, 4-2 and 4-3 accept that managerial innovation capacity (for example key arranging capacity and $R \& D$ capacity) effectsly affect management performance (way coefficients: $\beta=0.309[0.294], z=7.719, p<0.001$ for vital arranging; way coefficients:

$\beta=0.157[0.120], \mathrm{z}=4.482, \mathrm{p}<0.001$ for $\mathrm{R} \& \mathrm{D}$; way coefficients:

$\beta=0.248[0.192], \mathrm{z}=6.586, \mathrm{p}<0.001$ for innovation commercialisation). Accordingly, H4-1, H4-2, and H4-3 are supported.

To test speculation 5, the examination directed an interceded various leveled relapse investigation to confirm the directing impact of policy financial and management support. The fifth theory placed that when business enterprise influences managerial innovation exercises, policy financial support and management support will fill in as arbitrators.

Table 4 shows the consequences of the intervened various leveled relapse investigation performed to check the theory. The factual essentialness of the relapse coefficient for cooperations between the arbitrator factors and free factors was confirmed. The relapse coefficient for connections among business enterprise and policy financial and management support is measurably huge at $\beta=0.661, \mathrm{t}=12.28, \mathrm{p}<0.001$ for policy financial support and $\beta=0.271, \mathrm{t}=5.04, \mathrm{p}<0.001$ for management support for key arranging. The relapse coefficient for collaborations among enterprise and policy financial and management support isn't factually noteworthy at $\beta=0.003, \mathrm{t}=0.053, \mathrm{p}=0.958$ for policy financial support and $\beta=0.091, t=1.50, p=0.133$ for $R \& D$ for management support. The relapse coefficient for cooperations among enterprise and policy financial and management support is measurably noteworthy at $\beta=0.573, \mathrm{t}=10.29, \mathrm{p}<0.001$ for policy financial support and $\beta=0.239, \mathrm{t}=4.29, \mathrm{p}<0.001$ for management support for innovation commercialisation. 
The relapse coefficient for collaborations among key arranging capacity, R\&D capacity and innovation commercialisation capacity as subelements of managerial innovation exercises and policy financial support is factually noteworthy at $\beta=0.415, \mathrm{t}=$ $8.173, \mathrm{p}<0.001$ for vital arranging capacity; $\beta=0.095, \mathrm{t}=2.387, \mathrm{p}<0.05$ for $\mathrm{R} \& \mathrm{D}$ capacity; and

$$
\beta=0.260, t=5.810, p<0.001 \text { for innovation commercialization }
$$

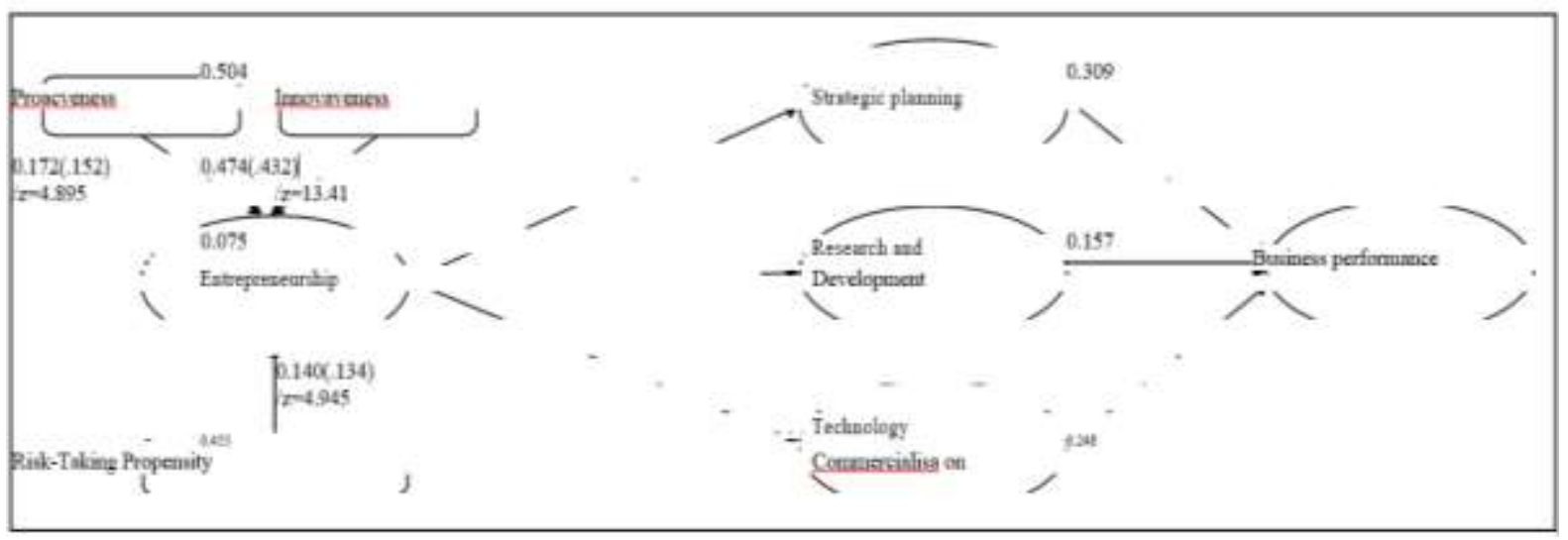

Figure 2. Path coefficients

Table 5. Effect of entrepreneurship on managerial innovation activities

\begin{tabular}{lllllllll}
\hline Variable & Items & $B$ & $\beta$ & $S E$ & $t$ & $p$ & Adjusted $R 2 F$ \\
\hline Strategic planning & - & - & - & - & - & 0.001 & 0.263, & 78.0 \\
(Constants) & - & 1.165 & - & 0.175 & 6.660 & 0.000 & - & - \\
Entrepreneurship & Innovativeness & 0.311 & 0.325 & 0.049 & 6.368 & 0.000 & - & - \\
& Proactiveness & 0.174 & 0.178 & 0.050 & 3.461 & 0.001 & - & - \\
Research and development capability & Risk-taking & 0.163 & 0.163 & 0.040 & 4.127 & 0.000 & - & - \\
(Constants) & - & - & - & - & $<0.001$ & 0.016 & 7.39 \\
Entrepreneurship & - & 2.295 & - & 0.247 & 9.240 & 0.000 & - & - \\
& Innovativeness & 0.190 & 0.165 & 0.069 & 2.754 & 0.006 & - & - \\
Technology commercialization & Proactiveness & 0.166 & 0.142 & 0.071 & 2.341 & 0.020 & - & - \\
(Constants) & Risk-taking & 0.162 & 0.135 & 0.056 & 2.891 & 0.004 & - & - \\
Entrepreneurship & - & - & - & - & 0.001 & 0.552 & 77.68 \\
& - & 1.224 & - & 0.199 & 6.165 & 0.000 & - & - \\
& Innovativeness & 0.585 & 0.539 & 0.055 & 10.57 & 0.000 & - & - \\
& Proactiveness & 0.005 & 0.005 & 0.057 & 0.091 & 0.927 & - & - \\
\hline
\end{tabular}

$\mathrm{B}$, unstandardised coefficient; $\beta$, standardised coefficient; SE, standard error.

Capacity for management performance. The regression coefficient for interactions among strategic planning capacity, R\&D capacity and technology commercialisation capacity as subelements of managerial innovation activities and management support is statistically significant at $\beta=0.352, \mathrm{t}$ $=6.165, \mathrm{p}<0.001$ for strategic planning capacity; $\beta=0.166, \mathrm{t}=3.693, \mathrm{p}<0.001$ for $\mathrm{R} \& \mathrm{D}$ capacity; and $\beta=0.253, \mathrm{t}=4.885, \mathrm{p}<0.001$ for technology commercialisation capacity for management performance. Thus, these results support H5-1, H5-3, H6-1, H6-2, and H6-3, but not H5-2. 


\section{Conclusion}

The control variables utilized in this study include service year, corporate size and industry. Size was measured by the number of full-time representatives, and industry was classified according to the Korean standard industrial arrangement into manufacturing, construction, distribution, services, and discount and retail trade. This study aims to examine the relationship among entrepreneurship and managerial innovation limit by considering subfactors, for example, innovativeness, proactiveness and risk-taking, just as to explore the relationship between managerial innovation limit and the executives performance. Precisely 820 subjects responded to this study questionnaire, and the study test comprised CEOs of SMEs from Korea. The organizations that had been doing business for fewer than 5 years comprised $12.9 \%(\mathrm{n}=106)$ of the example, while $18 \%(\mathrm{n}=148)$ had been founded $16-20$ years prior to the study, with $30.9 \%(n=253)$ being in presence for more than 20 years. Manufacturing ranked first among business types at 39.9\%, followed by specialized service organizations, broadcast communications, retail organizations and construction organizations. Organizations with fewer than five representatives comprised 29.1\% $(\mathrm{n}=239)$, while firms with more than 50 workers comprised $6.2 \%(\mathrm{n}=51)$.

From these findings, factors influencing creativity and business enterprise seem to incorporate endeavors to conceptualize thoughts for new item advancement, execution and improvement of new creation or operational frameworks and advancement of buyer situated mentalities and showcasing exercises. Such outlooks controlled by chiefs of SMEs are center variables in vital arranging, $R \& D$ and innovation commercialisation. Ingraining such an imaginative propensity in chiefs lays the foundation for the aim to grow new items, break down market circumstances, direct $\mathrm{R} \& \mathrm{D}$, use data examination and popularize advancements. Eventually, managerial innovation capacity varies as per administrators' inventive inclinations. Since R\&D capacity in SMEs is strengthened more by the mechanical support of aggregates and joint $R \& D$ ventures with national $R \& D$ offices than by financial support and management support from policy financing offices, the job of policy financing offices must be constrained.

At the point when vital arranging capacity and innovation commercialisation capacity, subfactors of managerial innovation capacity, influence management performance, policy money and management support gave by policy financing offices assume a directing job.

\section{Hypothetical and Managerial Implications}

In light of the after effects of this study, SMEs should improve their innovation capacity and extend creative business and policy money to accomplish seriousness, endure and show nonstop turn of events and development in an evolving situation. The down to earth consequences of this investigation are as per the following: initially, the examination furnishes SMEs with data they can use to build their familiarity with inside managerial innovation exercises, which are the first wellsprings of upper hand, and help advance R\&D and hierarchical management for nonstop support of innovation capacity. Also, this examination recommends that SMEs ought to use different outside assets, for example, policy financing organizations, to improve management performance through managerial innovation exercises.

Thirdly, the outcomes should make SME directors, including CEOs, mindful that inventive and creative business enterprise is straightforwardly identified with endurance and that managerial innovation exercises are significant techniques for defeating the 
inherent restrictions of SMEs. To help SMEs accomplish intensity and constant development in such a quickly changing managerial condition, this investigation meant to look at the impacts of enterprise on managerial innovation exercises, the impacts of managerial innovation exercises on management performance, and the directing job of policy money and management support. These Findings exhibit that business enterprise and managerial innovation exercises have an integral relationship. Hence, business enterprise with respect to SME chiefs has common associations with most managerial innovation exercises and influences management performance. This investigation recommends that SMEs, to have an upper hand, should give more consideration to managerial innovation in view of its extraordinary significance to business performance.

\section{References}

Albert, S., Ashforth, B.E., \& Dutton, J.E. (2000). Organizational identity and identification: Charting new waters and building new bridges. The Academy of Management Review, 25(1), 13-18. https://doi.org/10.5465/amr.2000.2791600.

Ade Yusuf (2021), The Influence of Product Innovation and Brand Image on Customer Purchase Decision on Oppo Smartphone Products in South Tangerang City,Budapest International Research and Critics Institute-Journal (BIRCI-Journal) 1(4),472-481 doi.org/10.33258/birci.v4i1.1629.

Al-Mamun, A., Kumar, N., Ibrahim, M.D., \& Bin Yusoff, M.N.H. (2017).Validating the measurement of entrepreneurial orientation.Economics and Sociology, 10(4), 51-66. https://doi.org/10.14254/2071-789X.2017/10-4/5

Alzuod, M.A., \&Kharabsheh, R. (2015).The influence of managerial innovation onfirm performance in Jordanian commercial banks. Conference on Business Management Research II (CBMR II 2015), Sintok, Kedah, Malaysia.

Bagozzi, R.P., \& Yi, Y. (1988).On the evaluation of structural equation models.Journalof the Academy of Marketing Science, 16(1), 74-94. https://doi.org/10.4236/jss.2016.43010

Bentler, P.M. (2004). EQS 6 equations manual. Encino, CA: Multivariate Software.

Bock, A.J., \& George, G. (2011).The business model in practice and its implications for entrepreneurship research.Entrepreneurship Theory and Practice, 35(1), 83-111. https://doi.org/10.1111/j.1540-6520.2010.00424.x

Buckley, M.R., Cote, J.A., \& Comstock, S.M. (1990). Measurement errors in the behavioral sciences: The case of personality/attitude research. Educational andPsychological Measurement, 50(3), 447-474. https://doi.org/10.1177/0013164490503001

Burgelman, R., Christensen, C., \& Wheelwright, S. (2009). Strategic management oftechnology and innovation.New York: McGraw-Hill Irwin.

Burns, T., \& Stalker, G.M. (1961).The management of innovation. London: Tavistock Publishing.

Cohen, W.A., \&Levinthal, D.A. (1990). Absorptive capacity: A new perspective on learning and innovation. Administrative Science Quarterly, 35(1), 128-152. https://doi.org/10.2307/2393553

Covin, J.G., \&Slevin, D.P. (1989).Strategic management of small firms in hostile and benign environments.Strategic Management Journal, 10(1), 75-87. https://doi.org/10.1002/smj.4250100107 
Covin, J.G., \&Slevin, D.P. (1991). A conceptual model of entrepreneurship as firm behaviour. Entrepreneurship Theory and Practice, 16(1), 7-26. https://doi. org/10.1177/104225879101600102

Covin, J.G., \& Wales, W.J. (2018). Crafting high-impact entrepreneurial orientation research: Some suggested guidelines. Entrepreneurship Theory and Practice, 43(1), 3-18. https://doi.org/10.1177/1042258718773181

Daugherty, P.J., Chen, H., \&Ferrin, B.G. (2011). Organizational structure and logistics service innovation. International Journal of Logistics Management, 22(1), 26-51. https://doi.org/10.1108/09574091111127543

Dess, G.G., \& Lumpkin, G.T. (2005).The role of entrepreneurial orientation in stimulating effective corporate entrepreneurship.Academy of ManagementExecutive, 19(1), 147-156. https://doi.org/10.5465/ame.2005.15841975

Drucker, P.F. (1985). Innovation and entrepreneurship practice and principles (pp. 150152). New York: Harper and Row.

Fornell, C., \& Larker, D. (1981).Evaluating structural equation models with unobservable variables and measurement errors.Journal of Marketing Research, 18(2), 39-50. https://doi.org/10.1177/002224378101800313

Frishammar, J., \&Horte, S.A. (2007).The role of market orientation and entrepreneurial orientation for new product development performance in manufacturing firms.Technology Analysis and Strategic Management, 19(6), 765-788. https://doi.org/10.1080/09537320701711231

Guan, J., \& Ma, N. (2003). Innovative capability and export performance of Chinese firms. Technovation, 23(9), 737-747. https://doi.org/10.1016/s0166-4972(02)00013-5

J. Jose Prabhu(2020): Perspectives and Empirical Study of Engineering College students towards Entrepreneurship, Konfrontasi Journal: Culture, Economy and Social Changes, 7 (4),331-342.DOI: https://doi.org/10.33258/konfrontasi2.v7i4.131

Rogers, M. (1998). The definition and measurement of innovation.MelbourneInstitute Working Paper Series, Melbourne Institute of Applied Economic andSocial Research, The University of Melbourne.

Short, J.C., Broberg, J.C., Cogliser, C.C., \& Brigham, K.C. (2009). Construct validation using computer-aided text analysis (CATA): An illustration using entrepreneurial orientation. Organizational Research Methods, 13(2), 320-347. https://doi.org/10.1177/1094428109335949

Van Zyl, H.J.C., \&Mathur-Helm. (2007). Exploring a conceptual model, based on the combined effects of entrepreneurial leadership, market orientation and relationship marketing orientation on south Africa's small tourism business performance. South African Journal of Business Management, 38(2), 17-24. https://doi.org/10.4102/sajbm.v38i2.580

Venkatraman, N., \&Ramanujam, V. (1986). Measurement of business performance in strategy research: A comparison of approaches. Academy of ManagementReview, 11(4), 801-814. https://doi.org/10.5465/amr.1986.4283976

Vozikis, G.S., Bruton, G.D., Prasad, D., \&Merikas, A.A. (1999).Linking corporate entrepreneurship to financial theory through additional value creation.Entrepreneurship Theory and Practice, 24(2), 33-43. https://doi.org/10.1177/104225879902400204

Wang, C., Lu, I., \& Chen, C. (2008).Evaluating firm technological innovation capability under uncertainty.Technovation, 28(6), 349-363. https://doi.org/10.1016/j.technovation.2007.10.007 
Westerberg, M., Singh, J., \&Hackner, E. (1997). Does the CEO matter? ScandinavianJournal of Management, 13(3), 251-270.

White, M.A., \&Bruton, G.D. (2007).Themanagement of technology and innovation:A strategic approach. Mason, $\mathrm{OH}$ : Thomson South-Western.

Wixom, B.H., \& Watson, H.J. (2001).An empirical investigation of the factors affecting data warehousing success.MIS Quarterly, 25(1), 17-32.

Yam, R.C.M., Pun, P.K., \& Tang, E.P.Y. (2004). An audit of technological innovation capabilities in Chinese firm: Some empirical findings in Beijing. Research Policy,33(8), 1123-1140. https://doi.org/10.1016/j.respol.2004.05.004

Yang, Z., Li-Hua, R., Zhang, X., \& Wang, Y. (2007). Corporate entrepreneurship and market performance: An empirical study in China. Journal of TechnologyManagement in China, 2(2), 154-163. https://doi.org/10.1108/17468770710756086 